\title{
PATOLÓGIÁS SZTENTEK VIZSGÁLATA
}

\section{EXAMINATION OF PATHOLOGICAL STENTS}

\author{
Asztalos Lilla ${ }^{1}$, Károly Dóra ${ }^{2}$ \\ ${ }^{I}$ Budapesti Müszaki és Gazdaságtudományi Egyetem, Gépészmérnöki Kar, Anyag- \\ tudomány és Technológia Tanszék. Magyarország, Budapest 1111, Bertalan L. u. 7.; \\ Tel.: +36-30-4522534, asztalos.lilla92@gmail.com \\ ${ }^{2}$ Budapesti Müszaki és Gazdaságtudományi Egyetem, Gépészmérnöki Kar, Anyag- \\ tudomány és Technológia Tanszék. Magyarország, Budapest 1111, Bertalan L. u. 7.; \\ Tel.: +36-1-4631114, kdora@eik.bme.hu
}

\begin{abstract}
Like in many European countries, also in Hungary a significant proportion of the deaths are caused by cardiovascular diseases. The effective treatment of stenosis is angioplasty. During the procedure, a balloon is advanced through the vascular system to the narrowing area. With the balloon also a metallic device called stent is expanded. After the intervention this device provides the free flow of blood in the vessel of the patient for life. Currently there are only few papers about the changes of a stent caused by the human organism. The stent cannot be removed from the patient, which seriously hampers research in this direction. Therefore, this study, which is dealing with explanted coronary stents, can be a step forward in this field. Our goal was to do non-destructive failure analysis on the explanted pathological stents; exploring the causes of visible damages and measuring the changes in the technical state.
\end{abstract}

Keywords: explanted coronary stent, failure analysis, non-destructive test.

\section{Összefoglalás}

Számos európai országhoz hasonlóan Magyarországon is a halálesetek jelentős hányadának hátterében szív- és érrendszeri megbetegedések állnak. Az érszükületek hatékony kezelési módja az angioplasztika. A beavatkozás során egy ballont az érrendszeren keresztül juttatnak el a szükület helyéig, ahol azt feltágítják. A ballonnal együtt egy ún. sztentet is feltágítanak, amely a ballon leeresztése után a szervezetben marad. Ez az eszköz biztosítja a beavatkozás után a vér szabad áramlását az adott érszakaszban egészen a páciens élete végéig. Jelenleg kevés irodalmi adat áll rendelkezésünkre a szervezet által okozott, a sztenteken végbement változásokról. Emiatt kutatásunk, amely explantált koszorúérsztentek vizsgálatával foglalkozik, elörelépés lehet ezen a területen. Célunk a patológiás sztentek roncsolásmentes károsodásvizsgálata volt; a sztenteken látható károsodások okainak feltárása és a müszaki állapotukban bekövetkezett változások mérése.

Kulcsszavak: patológiás koszorúersztent, károsodásvizsgálat, roncsolásmentes vizsgálat.

\section{Bevezetés}

A koszorúér-betegségek egyre elterjedtebbek a társadalom különböző rétegeiben. $\mathrm{Az}$ érelmeszesedés (arteriosclerosis) tehető felelössé a magyar statisztikák szerint a halálozás több mint 50 százalékáért, a középkorú lakosság szív- és érbetegségi halálozási aránya világviszonylatban a legnagyobbak között található [1]. 
A betegég egyik leghatékonyabb kezelési módja a sztentek alkalmazása. A sztent szilárd támasztó szerkezetként funkcionál az érfal számára, megakadályozva az érszakasz angioplasztika utáni visszaszúkülését [2].

\subsection{A szentek alapanyagai}

A sztentek alapanyagainak számos szigorú követelményt teljesíteni kell. A két legfontosabb tulajdonság élettani szempontból a bio- és hemokompatibilitás. Mechanikai szempontból a legfontosabb elvárások a megfelelő mértékü rugalmasság, illetve a képlékeny alakváltozás (feltágítás) utáni alaktartás, tehát képes legyen fenntartani a kívánt átmérőt. A leggyakrabban előforduló koszorúérsztent alapanyagok: kobalt-króm ötvözetek, platina-króm ötvözésü acélok vagy ausztenites korrózióálló acélok. Az acélok közül az X2CrNiMo18-14-3 (1.4435) anyagminőségü a legáltalánosabb kiváló korróziós tulajdonságai miatt [3].

\subsection{Sztentek igénybevételei}

A sztentek élettartamuk során számos és különböző igénybevételeknek vannak kitéve, amelyeket előállításuk során szem előtt kell tartani. Úgy kell kialakítani a végleges konstrukciót, hogy az alapanyaga és szerkezete képes legyen ellenállni nem csak a mechanikai, hanem a kémiai és korróziós igénybevételnek is. Számolni kell ezen kívül azzal is, hogy a sztent nem csupán a beültetése után, hanem a szükülethez juttatás során és tágítás közben is jelentős igénybevételnek van kitéve.

\section{Sztentek károsodásanalízise}

Sztentek károsodásával számos cikk foglalkozik, viszont a legtöbb publikáció orvosi oldalról közelíti meg a területet, klinikai esettanulmányokat írnak le, amennyire a rendelkezésükre álló orvosi diagnosztikai berendezésekkel (CT, röntgen stb.) térképezik fel az eszközt és környékét, kiváltképp akkor, ha a páciens még életben van [4].

A mérnöki megfigyeléseken alapuló kutatások végeselemes analízisen vagy in vitro vizsgálatokból állnak. A koszorúérsztentek károsodásvizsgálatának a legnagyobb akadálya az, hogy jelentős komplikációk nélkül a sztentet nem lehet a páciensből eltávolítani. Így tehát a sztent komolyabb analizálására a beteg halála utáni explantációt követően van lehetöség [5].

\section{A vizsgálatok leírása, célja}

$\mathrm{Az}$ általunk használt mintákat explantálás során az érszakaszokkal együtt távolították el a szervezetből. A mintadarabokról a plakkot és az azt tartalmazó érfalat kémiai úton távolíttuk el [6].

A rendelkezésre álló darabokon Olympus SZX16 sztereomikroszkóp segítségével a mintázat, a sztent alakjának és névleges méreteinek változását figyeltük meg. A sérült sztentek töretfelületeit Philips XL 30 pásztázó elektronmikroszkóppal vizsgáltuk. EDAX Genesis energiadiszperzív röntgenspektrométerrel (EDS) a sztentek anyagösszetételét is ellenőriztük.

\subsection{A rendelkezésre álló darabok}

A kutatás során használt mintákat az I. sz. Patológiai és Kísérleti Rákkutató Intézet bocsájtotta rendelkezésünkre. A kísérletsorozat TUKEB engedélyszáma: 146/2012.

Jelen cikkben két kiválasztott patológiás sztent vizsgálatával foglalkozunk. Az (A) jelü sztent 1.4435 alapanyagú, hatóanyagos bevonattal gyártott sztent (DES). A (B) jelü sztent Co-Cr ötvözet alapanyagú, bevonat nélküli fémsztent (BMS). Rendelkezésünkre álltak a sztentek beültetésének konkrét körülményei: névleges méretei, tágítási nyomás, kórelőzmény. A gyártó által megadott adatok alapján a (B) sztent hossza 28 $\mathrm{mm}$, átmérője 2,5 mm. Az (A) sztent esetében az adatok hiányosak, így a befoglaló méreteket nem tudjuk. A beültetés és az 
explantálás között eltelt idő az (A) sztent esetén 5 év, a (B) sztent esetén 1 nap volt.

\subsection{Sztereomikroszkópos vizsgálatok}

Az (A) jelzésü minta sztereomikroszkópos felvételén (1. ábra) jól látható, hogy a sztent bordái több helyen eltörtek, a minta szinte kettévált az érszakasz leválasztása után. Az adott darabról az érszakasz eltávolítása előtt CT-felvételt készítettek, amelyen szintén látható volt a sztent károsodása, így nagy biztonsággal állítható, hogy a sztent nem a kísérletek során sérült.

A (B) jelü mintán szintén láthatóak károsodott bordák, az érszakasz eltávolítása után a sztent két darabra vált (2. ábra).

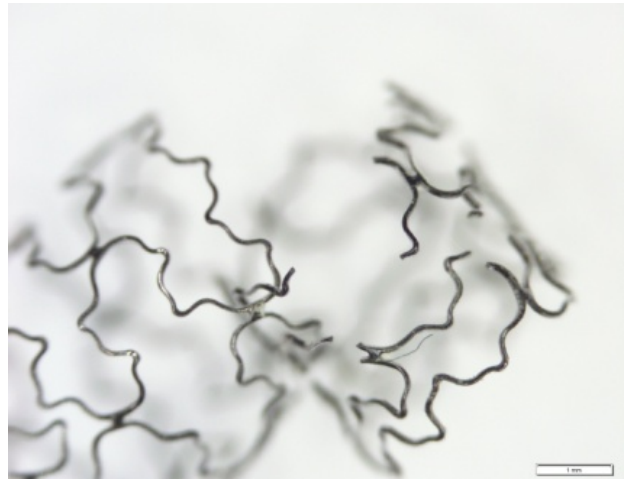

1. ábra. $A z$ (A) mintán jól látható törött bordák

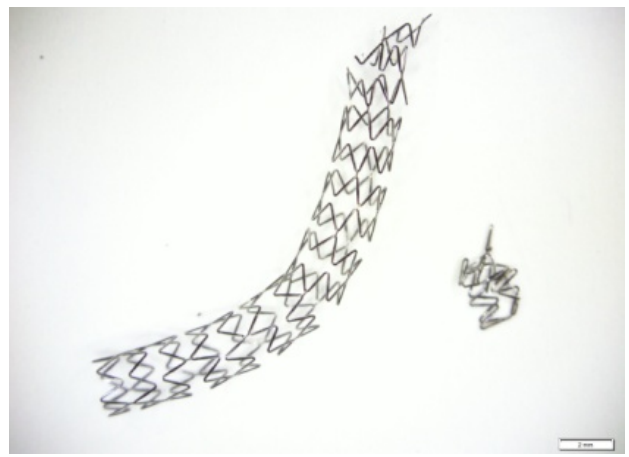

2. ábra. $A$ (B) minta nagymértékü károsodása, az érszakasz eltávolitása után két különálló darabra vált
A (B) minta esetében a bordák végét megfigyelve látható, hogy a töretfelületek egy sík mentén helyezkednek el, amelyből arra következtettünk, hogy a darabot explantálás közben elvágták (3. ábra).

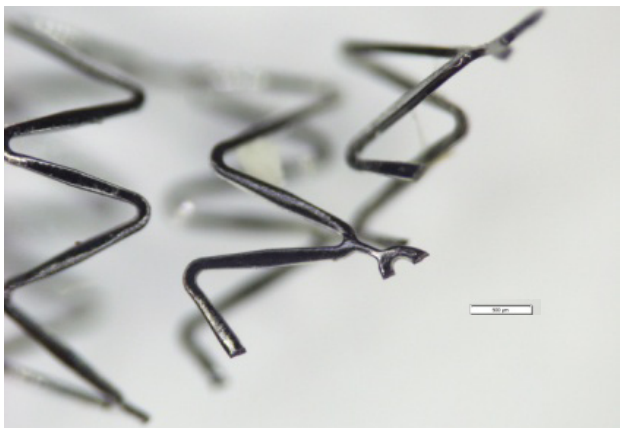

3. ábra. $A(B)$ sztent károsodott bordái

\subsection{Pásztázó elektronmikroszkópos vizsgálat}

A pásztázó elektronmikroszkópos képeken a (B) minta esetében a felületeken egyértelmüen vágás nyoma fedezhető fel. A nagy kiterjedésü szabályos síkok, és a vágószerszám élének haladását jelző apró rovátkák alapján megállapítottuk, hogy az explantálás során alkalmazott eszközök okozták a sérülést (4. ábra).

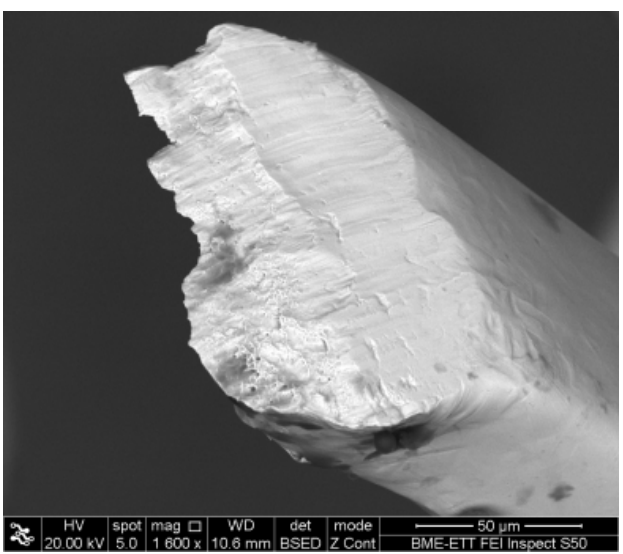

4. ábra. (B) minta felületén levő vágásnyomok 
Az (A) minta töretfelületein már nem figyelhettük meg a külső behatásra jellemző nyomokat.

Az 5. ábrán látható töretfelület minősítése nem egyértelmü, a felületet a törés után koptató hatás érhette, mivel sok helyen ,elkenődött" a töret. A borda oldalán különböző mértékü benyomódások, apró repedések figyelhetőek meg, ami szintén arra utal, hogy a törés bekövetkezte után az egymással szemben álló bordafelek többször egymásnak ütődtek.

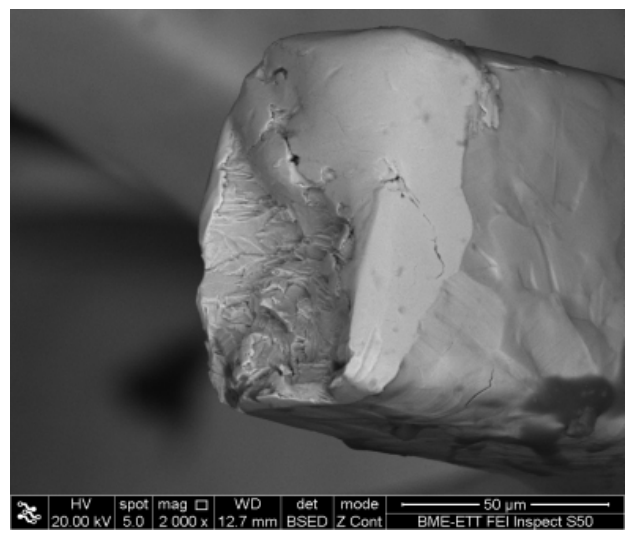

5. ábra. Töretfelület az (A) mintán

A 6. ábrán az (A) minta egy másik bordáján található töretfelület látható. A felület jellege fáradásos törésre utal, viszont a korábban említett koptatóhatás miatt a töretfelület minősítése nem egyértelmü.

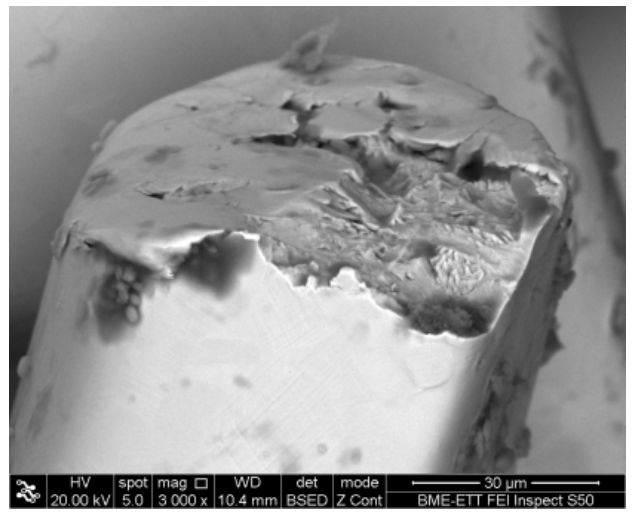

6. ábra. Töretfelület az (A) mintán
Az EDS vizsgálat eredménye alapján elmondhatjuk, hogy a minták anyagai a gyártók által megadott összetétellel megközelítőleg megegyeztek.

\section{Következtetések}

Vizsgálataink legföbb célkitüzése volt, hogy a rendelkezésünkre álló mintadarabok állapotát minél több szempontból vizsgáljuk roncsolásmentesen. A nagymértékben károsodott sztentek töretfelületeit pásztázó elektronmikroszkóppal is ellenőriztük, feltárandó a tönkremenetel okait. A töretfelületek közül többről is bebizonyosodott, hogy explantálás közben, külső behatásra sérülhetett a sztent, néhány töretfelület esetében pedig a törési felület erősen kopott jellege egyértelmüen arra utalt, hogy a törés már régebben bekövetkezett.

\section{Szakirodalmi hivatkozások}

[1] Finegold JA, Asaria P, Francis DP: Mortality from ischaemic heart disease by country, region, and age. Int J Cardiol 168:2 (2013) pp.934-945.

[2] Mann DL, Zipes DP, Libby P, et al.: Braunwald's Heart Disease. Ch. 1. SaundersElsevier, 10th edition, Philadelphia, 2014.

[3] Dobránszky J: Az értágítóbetétek anyagainak fejlödése. Bányászati és kohászati lapok - Kohászat, 2013, 146. évf. 5-6. szám, pp.44-48.

[4] Nakazawa G, Finn AV, Vorpahl M, et al.: Incidence and predictors of drugeluting stent fracture in human coronary artery a pathologic analysis. J Am Coll Cardiol 54:21 (2009) pp.1924-31.

[5] Kertész A, Bognár E, Dévényi L: Sztentek károsodásanalizise. Anyagok világa, 2013, pp.36-42.

[6] Károly D, Charalambous D, Pogácsás B, et al.: Preparation method for investigation of explanted coronary stents. 32th DAS Proceedings, 2015. 